\title{
Novel humanized anti-CD20 monoclonal antibodies with unique germline VH and VL gene recruitment and potent effector functions
}

\author{
MICHIO NISHIDA ${ }^{1}$, KEISUKE TESHIGAWARA ${ }^{1}$, OTSURA NIWA ${ }^{1}$, SADAKAZU USUDA $^{2}$, \\ TETSUO NAKAMURA ${ }^{2}$, PETER RALPH $^{3}$, ROLAND NEWMAN $^{4}$ and EDUARDO A. PADLAN ${ }^{5}$ \\ ${ }^{1}$ Late Effects Studies, Radiation Biology Center, Kyoto University, Yoshida-Konoe-cho, Sakyo-ku, Kyoto 606-8501; \\ ${ }^{2}$ BioMedics Japan, Inc., 1-1-10 Koraku, Bunkyo, Tokyo 112-0004, Japan; ${ }^{3}$ Marin Biologic Laboratories Inc., \\ 3152 Paradise Drive Tiburon, CA 94920; ${ }^{4}$ RANA Consulting, 8919 Montrose Way, San Diego, CA 92122, USA; \\ ${ }^{5}$ Marine Science Institute, College of Science, University of the Philippines, Quezon City 1101, Philippines
}

Received January 22, 2008; Accepted March 20, 2008

\begin{abstract}
The anti-CD20 chimeric monoclonal antibody $(\mathrm{mAb})$ rituximab is the most widely used therapeutic antibody for B-cell malignancies. However, $50 \%$ of non-Hodgkin's lymphoma (B-NHL) patients respond to treatment with this antibody. Novel humanized antibodies target membrane CD20 with enhanced effector properties should improve treatment for a broader patient population with relapsed and refractory disease. A novel chimerized form of the murine anti-CD20 1K1791 exerts more potent antibody-dependent cellular cytotoxicity (ADCC) and complement-dependent cytotoxicity (CDC) activities and induces cell death by a non-caspase dependent process. Humanized mAbs derived from 1K1791 were designed using four different humanization techniques and characterized. In contrast to rituximab or $2 \mathrm{~F} 2$ (human anti-CD20 mAb), several of these exhibited superior ADCC, CDC, inhibition of cell growth and cell death. There was a wide range of functional differences among the humanized forms of 1K1791 despite a modest replacement of amino acid residues in the CDRs. To determine whether the superior activities exhibited by parental murine mAb 1K1791 were due to differences in VH and VL rearrangement, we analyzed its germline and compared it to other anti-CD20 mAbs. A remarkable conservation of $\mathrm{VH}$ and $\mathrm{Vk}$ (VL kappa) gene usage was observed in the murine anti-CD20 mAbs. $18 / 23$ used the same germline gene J558.42 and 4/23 used
\end{abstract}

Correspondence to: Michio Nishida, Late Effects Studies, Radiation Biology Center, Kyoto University, Yoshida-Konoe-cho, Sakyo-ku, Kyoto 606-8501, Japan

E-mail: minishida@aol.com

Key words: anti-CD20 monoclonal antibody, humanized, germline gene family, binding epitope, apoptosis, antibody-dependent cellular cytotoxicity, complement-dependent cytotoxicity closely related genes of the 'J558' group. Thus, 22/23 belonged to VH1 family. One exception was the mAb $1 \mathrm{~K} 1791$, which was derived from the $V H 9.12$ germline gene. $1 \mathrm{~K} 1791$ was also unique in its use of a Vk19/28 family gene whereas most other mAbs (21/23) used Vk4/5 family genes. A formal relationship between the particular germline gene recruitment and antibody functionality has not been established, however, the present findings identified humanized mAbs with functional activities that were superior to rituximab and $2 \mathrm{~F} 2$. These in vitro results support future in vivo animal testing and subsequent clinical trials.

\section{Introduction}

Different anti-CD20 mAbs have been shown to have diverse functional properties and epitope specificities and mediate varied effects on cell death either by direct transmembrane signaling or other cytotoxic mechanisms (1-3). Further, CD20 mAbs have been shown to sensitize tumor cells to both chemotherapy and immunotherapy $(4,5)$. The exact function of the CD20 molecule is unknown. It has no known ligand and is purported to act as an ion channel to facilitate re-entry of intracellular calcium following BCR-induced efflux (6).

CD20 is a member of the membrane-spanning $4 \mathrm{~A}$ gene family (MS4A). The size of the molecule is $33-35 \mathrm{kD}$ but with only about 43 amino acids exposed on the extracellular surface. Deletion mutant studies by Polyak et al (7) demonstrated that the sequence AxP at position 170-172 is important in determining the secondary structure of the extracellular loops to allow antibody binding. However, it is not clear whether the sequence itself represents a contact point for CD20 antibody binding or is only responsible for maintaining a particular structural configuration. Most functional anti-CD20 mAbs do not react with synthetic linear epitopes or denatured antigen, suggesting that even though the extracellular portion is small there must be sufficient secondary structure to establish conformational epitopes. All of the monoclonal antibodies described to date that 
recognize the extracellular loops, not surprisingly, partially or completely cross-block each other's binding (8-10). The binding specificities of several different antibodies were dissected by Polyak et al (7) who defined seven different patterns of binding, although many shared similar or overlapping epitopes with those already defined by other groups (11). Further, they showed that the mAb 1F5, which activates resting $\mathrm{B}$ cells, differed from the other mAbs in its inability to precipitate CD20 from detergent lysates. They concluded that the functional reactivity of 1F5 was dependent on the integrity of the CD20 oligomeric complex on the cell surface.

Although most CD20 mAbs exhibit CDC (complementdependent cytotoxicity), and ADCC (antibody-dependent cellular cytotoxicity) in vitro and many exhibit apoptotic activity, the in vivo mechanisms of cell killing are far from clear. The activities of rituximab and ofatumumab are thought to be predominantly through CDC and ADCC $(12,13)$; although a number of other anti-CD20 antibodies appear to operate in the absence of effector functions.

The overall response rate (complete response plus partial response) of B-NHL patients treated with rituximab $\sim 50 \%$. It is not clear why the remaining patients, though their tumors express CD20, do not sufficiently respond to treatment. In a recent study, we have reported on the generation of several murine anti-CD20 mAbs and demonstrated that many exhibited higher functional activities compared to 2B8 (the murine parental $\mathrm{mAb}$ for rituximab) or rituximab (14). We speculated such novel anti-CD20 mAbs with enhanced effector functions and different biological activities might potentiate the clinical response. One murine mAb in particular, $1 \mathrm{~K} 1791$, showed significant direct inhibition of growth in several malignant B-cell lines. We assumed, therefore, that the generation of chimeric and humanized mAbs forms of $1 \mathrm{~K} 1791$ would maintain or exceed the superior activities observed with murine $1 \mathrm{~K} 1791$.

The present study was designed to test the above hypotheses and the following were investigated: i) characteristics of chimeric anti-CD20 mAbs and humanized mAbs derived from 1K1791; and ii) examination of the relationship between $\mathrm{V}$ gene usage of anti-CD20 antibodies and their functional activities in vitro, such as direct inhibition of cell growth and apoptosis, in comparison with 2B8. Eight murine antiCD20 mAbs were selected and chimerized for comparison with rituximab for $\mathrm{CDC}$ and $\mathrm{ADCC}$ activities. One of these antibodies was selected for humanization based on the outcome of functional experiments with both original murine and the chimeric versions. The murine antibody parent was then subjected to a number of different humanization techniques.

\section{Materials and methods}

Cells and antibodies. The CD20+ cell lines, Raji (Burkitt's lymphoma) and CCRF-SB (acute lymphoblastic leukemia) were obtained from JCRB (Riken Bioresource Center, Tsukuba, Japan). The SU-DHL4 (Diffuse large cell type BNHL) and RC-K8 (Histiocytic lymphoma) were obtained from DSMZ GmbH (Braunschweig, Germany). CHO DG44 was from Invitrogen Japan (Tokyo, Japan) (15). The hybridoma producing murine anti-CD20 mAbs, with the prefix ' $1 \mathrm{~K}$ ', were described in our previous report (14). Rituximab (chimeric anti-CD20 mAb) and 2B8 were obtained from Zenyaku Kogyo (Tokyo, Japan) and infliximab was from Tanabe Pharmaceutical (Osaka, Japan). 2F2, human anti$\mathrm{CD} 20 \mathrm{mAb}$ also known as ofatumumab, was generated through reverse engineering of the $2 \mathrm{~F} 2$ DNA sequences described in the US patent publication and transfecting them into $\mathrm{CHO}$ cells (16).

Gene family analysis. Amino acid sequences of hybridoma producing anti-CD20 mAbs, as well as the published anti$\mathrm{CD} 20 \mathrm{mAb}$ sequences, were assigned to germline variable genes. This was done by comparison to $97 \mathrm{Vk}$ and $284 \mathrm{VH}$ individual germline genes and their families from GenBank (National Center for Biotechnology Information, Bethesda, MD) and three other publications (17-19).

Chimeric antibody development. The murine anti-CD20 mAbs were chimerized as murine/human IgG1/kappa versions (designated with the prefix ' $\mathrm{c} 1 \mathrm{~K}$ ' ( $\mathrm{c} 1 \mathrm{~K}$ mAbs) and the $\mathrm{Vk}$ and VH DNA sequences inserted into pNOW-ab, a modified version of pNOW (20), for antibody expression in $\mathrm{CHO}$ DG44 cells.

Humanized antibody development. The humanized sequences were designed using four different humanization techniques. These were a) by 'veneering', whereby the exposed framework residues were replaced by amino acids found at corresponding positions in human antibody sequences $(21)$; b) 'grafting of abbreviated CDRs', whereby only the parts of the CDRs, which contain antigen-contacting residues in antibody:antigen complexes of known three-dimensional structure, were grafted onto the most homologous human variable domains (22); c) 'SDR-transfer', whereby only the residues in direct contact with antigens, were transferred into the most homologous human domains (22); and d) grafting the whole CDRs onto a composite framework built from the most homologous segments from different human variable domains (23). In b), c) and d), human germline sequences were used. The sequences humanized using a), b), c) and d) were labeled 'ven', 'abb', 'sdr' and 'fra', respectively.

The conversion of amino acids to nucleotides was done with reference to the consensus DNA sequences of human immunoglobulin Vk and VH genes in GenBank. The nucleotide sequences of humanized $\mathrm{Vk}$ and $\mathrm{VH}$ were synthesized by Hokkaido System Science (Sapporo, Japan) inserted into pNOW-ab and transfected into CHO DG44 cells with assistance from the Bacteriology Division at the Tottori University (Yonago, Japan). The humanized anti-CD20 mAbs derived from 1K1791 were named by the abbreviated names of the humanization technique used for both light and heavy chains, i.e. light chain/heavy chain: abb/abb, abb/fra, $\mathrm{abb} / \mathrm{sdr}, \mathrm{abb} / \mathrm{ven}, \mathrm{fra} / \mathrm{abb}, \mathrm{fra} / \mathrm{fra}, \mathrm{fra} / \mathrm{sdr}, \mathrm{fra} / \mathrm{ven}, \mathrm{sdr} / \mathrm{abb}$, sdr/fra, sdr/sdr, sdr/ven, ven/abb, ven/fra, ven/sdr and ven/ven, respectively. Amino acid replacements are shown in Table I.

Inhibition of cell growth by murine mAbs or humanized $m A b s$. A total of 19 murine and 16 humanized anti-CD20 mAbs originating from $1 \mathrm{~K} 1791$ were used in this study to 
Table I. Amino acid replacement during humanization.

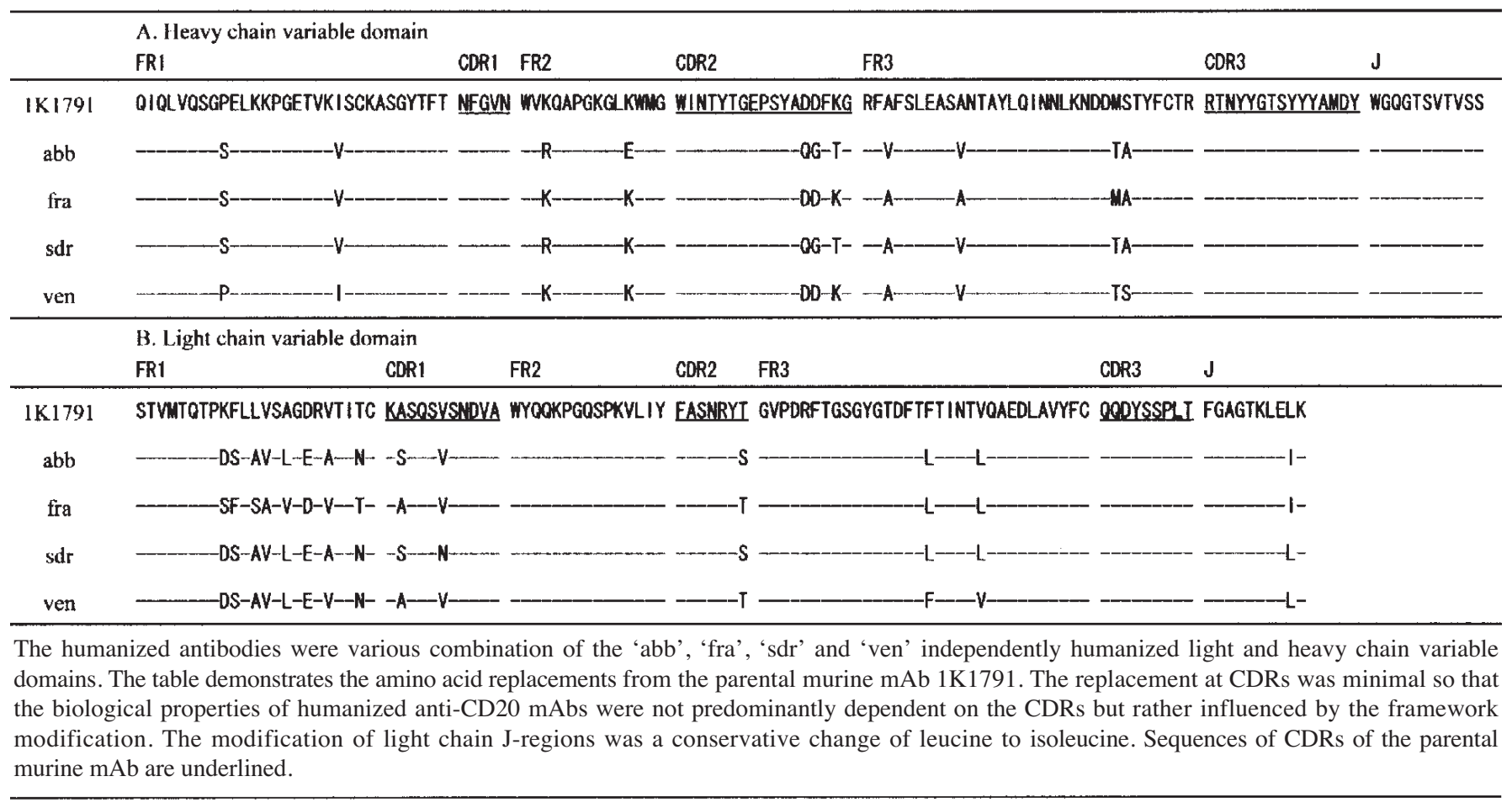

define their inhibitory effects on the growth of Raji or SUDHL4 cells in the absence of lytic components. The studies were done in a concentration and time-dependent manner using either $0.3 \mu \mathrm{g} / \mathrm{ml}$ or $1.0 \mu \mathrm{g} / \mathrm{ml}$ after 24,48 and $83 \mathrm{~h}$ of continuous culture for the murine mAbs, and $0.5 \mu \mathrm{g} / \mathrm{ml}$ after 24 and $81 \mathrm{~h}$ for the humanized mAbs, respectively. The concentration used for humanized mAbs was determined in reference to the results of murine $\mathrm{mAb}$ studies suggesting $0.3-1.0 \mu \mathrm{g} / \mathrm{ml}$ was appropriate to examine. Chromogenic reagent (Cell Counting Kit-8, Dojindo Laboratories, Kumamoto, Japan) was added and incubated for an additional $4 \mathrm{~h}$. The plates were then read in a micro-plate reader (Hitachi High-Technologies, Tokyo, Japan) and the absorbance at $492 \mathrm{~nm}$ was recorded. The cell growth in the presence of each antibody was compared to that without antibody and the inhibition determined. The murine mAbs were compared to $2 \mathrm{~B} 8$ and humanized mAbs compared to rituximab and $2 \mathrm{~F} 2$.

$C D C$ assay of chimeric $m A b$ s or humanized $m A b s$. The ability of chimeric mAbs to promote $\mathrm{CDC}$ against RC-K8 cells or humanized mAbs against RC-K8 and SU-DHL4 cells was examined using the methods of Gazzano-Santoro et al (24) and Idusogie et al (25). The chimeric mAbs were compared with rituximab and humanized mAbs compared with rituximab and 2F2. Infliximab and human complement (Quidel, San Diego, CA) solution without antibody were used as negative controls and Triton X-100 was used to give a maximum value of cell lysis. Each of the test antibodies was diluted with RHB buffer; RPMI-1640, $0.1 \%$ bovine serum albumin (BSA) (Sigma, St. Louis, MO), $20 \mathrm{mM}$ HEPES at pH 7.2, $2 \mathrm{mM}$ glutamine, $100 \mathrm{IU} / \mathrm{ml}$ penicillin and $100 \mu \mathrm{g} / \mathrm{ml}$ streptomycin resulting in $0.01-10.0 \mu \mathrm{g} / \mathrm{ml}$ of chimeric antibodies with
RC-K8 cells. A range of $0.08-10.0 \mu \mathrm{g} / \mathrm{ml}$ was applied to the humanized antibodies with either RC-K8 or SU-DHL4 cells The cells were washed in RHB buffer and re-suspended at $1 \times 10^{6}$ cells $/ \mathrm{ml}$ density and $50 \mu 1$ of the cell suspension was loaded into 96-well TC black plate (Nunc A/S, Roskilde, Denmark). Each antibody solution $(50 \mu \mathrm{l})$ was added with $50 \mu 1$ of human serum complement and cell suspension and incubated thereafter at $37^{\circ} \mathrm{C}$ for $2 \mathrm{~h}$. Alamar blue (BioSource, Camarillo, CA) was added and the culturing continued for another $18 \mathrm{~h}$. Heat-inactivated human serum complement was used as a negative control. The plate was quenched at room temperature for $10 \mathrm{~min}$. Fluorescence was read using a 96-well fluorometer with excitation at $530 \mathrm{~nm}$ and emission at $590 \mathrm{~nm}$. The results are expressed in relative fluorescence units (RFU) which are proportional to the number of viable cells. The activity of various sample antibodies was examined by plotting the CDC activity by percent against the log of antibody concentration, present before the addition of Alamar blue, using 4-parameter curve fitting program (Kaleidagraph).

ADCC assay of chimeric $m A b$ or humanized mAbs. The ADCC of chimeric mAbs or humanized mAbs against RCK8 and SU-DHL4 cells was assayed according to a standard protocol (26). Peripheral blood mononuclear cells (PBMC) were isolated from blood of three normal donors (A, B and C) by Ficoll-Hypaque separation (GE Healthcare/Amersham Biosciences, Piscataway, NJ) as effector cells and washed twice with Hanks Balanced Salt Solution (Invitrogen) to remove platelets, and re-suspended in RPMI media with $10 \%$ heat-inactivated fetal bovine serum (HIBS) $\left(5 \times 10^{6}\right.$ cells $\left./ \mathrm{ml}\right)$ and antibiotics. An E:T ratio (effector cells to target cells) of 50:1 was used. The chimeric mAbs were compared with 
rituximab and the humanized antibodies compared with rituximab and $2 \mathrm{~F} 2$. Infliximab was used as a negative control for both studies. Target cells were labeled with $1 \mathrm{mCi}$ of ${ }^{51} \mathrm{Cr}$ $\left(1 \mathrm{mCi} / \mathrm{ml} \mathrm{Na}_{2} \mathrm{CrO}_{4} / 6 \times 10^{6}\right.$ cells, GE Amersham) for $1 \mathrm{~h}$ and incubated at $37^{\circ} \mathrm{C}$ for $2 \mathrm{~h}$ with PBMC in the presence of antibody. The cells were washed twice, incubated at $37^{\circ} \mathrm{C}$ for $15 \mathrm{~min}$ and then washed twice again. The cells were counted and re-suspended in RPMI media with $15 \%$ HIBS at $1 \times 10^{5}$ cells $/ \mathrm{ml} .{ }^{51} \mathrm{Cr}$ labeled target cells $(100 \mu \mathrm{l})$ were added to each well $\left(1 \times 10^{4}\right.$ cells $\left./ \mathrm{ml}\right)$ with $100 \mu 1$ of sample antibody solution (30 $\mu \mathrm{g} / \mathrm{ml})$. The final concentration of sample antibody was $10 \mu \mathrm{g} / \mathrm{ml}$. The supernatant was removed for quantification of ${ }^{51} \mathrm{Cr}$ release. Controls with target cells and PBMC but no antibody determined spontaneous ${ }^{51} \mathrm{Cr}$ release for individual assays. Triton (5\%) was used as a measure of complete cell lysis. Four replicates were performed for each sample.

Affinity measurement and competitive binding assay by ${ }^{125} I-$ labeled antibody. The assay of equilibrium dissociation constant $(\mathrm{Kd})$, total amount of antibody bound to the target cells $\left(\mathrm{B}_{\max }\right)$ and $\mathrm{EC}_{50}$ were performed according to standard protocols. The ${ }^{125}$ I-labeled antibody was prepared using sodium [ $\left.{ }^{125} \mathrm{I}\right]$-iodide and Iodogen (GE Healthcare/Amersham Biosciences), purified by size exclusion chromatography and diluted in PBS with $0.25 \%$ BSA. Raji cells were incubated in RPMI-1640 with $10 \%$ fetal bovine serum (FBS) plus antibiotics in the presence of a range of antibody concentration under equilibrium conditions. Detection of ${ }^{125} \mathrm{I}$-labeled antibody bound to cells after thorough washing was performed on a gamma counter. All data analyses were performed using non-linear regression curve fitting provided by GraphPad Prism software (version 3.02) (27). Competition of rituximab binding to target cells by the humanized anti-CD20 mAbs or cold rituximab was also measured.

Cytotoxicity by apoptosis or necrosis. Apoptosis and necrosis induced by humanized mAbs were measured by flow cytometry using the Annexin V/FITC and propidium iodine (PI) staining methods (Annexin V/FITC apoptosis detection kit, BD Biosciences, Franklin Lakes, NJ). This method allows the examination of live cells (Annexin $/ \mathrm{PI}^{-}$), early stage of apoptosis (Annexin $\left.{ }^{+} / \mathrm{PI}^{-}\right)$, late-stage of apoptosis (Annexin ${ }^{+}$ $\mathrm{PI}^{+}$) and necrotic cells (Annexin-/PI'). Eleven humanized and three control antibodies-rituximab and $2 \mathrm{~F} 2$ as positive controls and murine anti-CD3 mAb as a negative control (BioLegend, San Diego, CA) were tested against RC-K8 and Raji cells. Goat anti-human IgG (Jackson Immunoresearch Laboratories, West Grove, PA) was used as a cross-linking antibody. The amount of each antibody used in this study was $10 \mu \mathrm{g} / \mathrm{ml}$. RC-K8 cells were maintained in RPMI-1640 media with $15 \%$ FBS plus antibiotics and Raji cells were in RPMI-1640 with $10 \%$ FBS plus antibiotics. Cells $\left(5 \times 10^{5}\right.$ cells $\left./ \mathrm{ml}\right)$ were sub-cultured for one or two days prior to seeding for the assay, to assure the cells were in logarithmic growth at the start of the assay and then incubated in duplicate with $10 \mu \mathrm{g} / \mathrm{ml}$ test or control antibodies, in the presence or absence of $10 \mu \mathrm{g} / \mathrm{ml}$ cross-linking antibody. Following incubation for $24 \mathrm{~h}$, cells were pelleted and washed in PBS, re-suspended in FACS staining buffer, and stained with Annexin V/FITC and PI, according to the manufacturer's specification. Flow cyto- metry was performed with a FACS Calibur 2 and analyzed by CellQuest software (BD Biosciences).

Analysis of caspase activation. Three humanized anti-CD20 mAbs, sdr/abb, sdr/fra and abb/abb, that demonstrated greater relative apoptosis values compared to other humanized antibodies, were used in the activation study of caspase-3, 7 and 9 (Promega, Madison, WI) using Raji cells as the target. Rituximab was used as a control. Antibodies were incubated in the presence or absence of a cross-linking antibody, goat anti-mouse IgG for murine antibodies or goat anti-human IgG for humanized antibodies (Pierce Biotechnology, Rockford, IL). Anti-CD3 $\mathrm{mAb}$ and infliximab were used as negative controls. Samples were incubated for $24 \mathrm{~h}$ and caspase activity was measured using a commercial detection assay with luminescence readout. Raji cells were incubated in RPMI-1640 containing $10 \% \mathrm{HIBS}$ and penicillin/streptomycin at $37^{\circ} \mathrm{C}$ and sub-cultured every 2-3 days. Raji cells were plated at $100 \mu \mathrm{l} /$ well in a 96 -well flat bottom TC plate. Test and control antibodies $(5-10 \mu \mathrm{g} / \mathrm{ml})$ were added in the presence or absence of cross-linking antibody $(5-10 \mu \mathrm{g} / \mathrm{ml})$. Ionomycin (1 $\mu \mathrm{M}$; EMD Chemicals, San Diego, CA) treated cells served as an additional positive control. A pan-caspase inhibitor, zVAD-fmk (Promega), was added to some wells (10-20 $\mu \mathrm{M})$, to demonstrate specificity. Cells were incubated for up to $48 \mathrm{~h}$. An equal volume of caspase-3, -7 or -9 substrate was added and the plates were agitated on a tabletop shaker for $30 \mathrm{sec}$ at $300 \mathrm{rpm}$ and further incubated at room temperature from 45 min to $2 \mathrm{~h}$ (based on the Promega technical bulletin of Caspase-Glo ${ }^{\mathrm{TM}}$ 3/7 Assay System: TB323, Caspase-Glo ${ }^{\mathrm{TM}}$ 9 Assay System). The luminescence was read after 1 and $2 \mathrm{~h}$ with a Wallac Victor2 plate reader (Perkin-Elmer, Waltham, MA).

\section{Results}

Potentiation of effector functions of chimeric and humanized anti-CD20 mAbs in comparison with rituximab and $2 F 2$; Complement-dependent cytotoxicity (CDC). Our recent findings demonstrated that the novel murine anti-CD20 mAb 1K1791 exhibited unique cytotoxic effects in comparison with several other generated mAbs and rituximab (14). Consequently, we generated chimeric mAbs from several murine anti-CD20 mAbs and examined their effector properties. Analysis of CDC against the RC-K8 cells revealed that the chimeric mAb c1K1791 was the most cytotoxic with $\sim 75 \%$ of cell death at a concentration of $10 \mu \mathrm{g} / \mathrm{ml}$ whereas the other chimeric mAbs induced cytotoxicity ranging from $10-50 \%$ when used at the same concentration. Rituximab showed $29 \%$ cytotoxicity. At a lower concentration of $1.0 \mu \mathrm{g} / \mathrm{ml}$, chimeric 1K1791 (c1K1791) induced 50\% cell death whereas the other mAbs showed $5-40 \%$ and rituximab gave $18 \%$ (Fig. 1A).

The humanized mAbs derived from 1K1791 were tested for CDC against both RC-K8 and SU-DHL4 cells. All of the humanized antibodies except for fra/ven induced up to $80 \%$ of cell death against RC-K8 cells (Fig. 1B) and close to $100 \%$ against SU-DHL4 cells (Fig. 1C) at $10 \mu \mathrm{g} / \mathrm{ml}$ concentration. By comparison, the humanized antibodies, excluding fra/ven, were more cytotoxic against RC-K8 cells 
than rituximab (5-6-fold) and $2 \mathrm{~F} 2(>120 \%)$ at $10 \mu \mathrm{g} / \mathrm{ml}$ concentration. More significant differences of cytotoxicity of the humanized antibodies against RC-K8 cells were seen at a lower concentration. However, there was only a slight difference among antibodies with SU-DHL4 cells and this cell line was more sensitive than RC-K8.

The above findings demonstrate that humanized and chimeric antibodies from $1 \mathrm{~K} 1791$ were more cytotoxic than rituximab and $2 \mathrm{~F} 2$ against RC-K8 cells. The cytotoxicity of humanized antibodies was slightly higher than rituximab or 2F2 with SU-DHL4 cells. The findings also established that humanization retained the CDC activity of the chimeric $\mathrm{mAb}$ in most cases.

\section{A.}

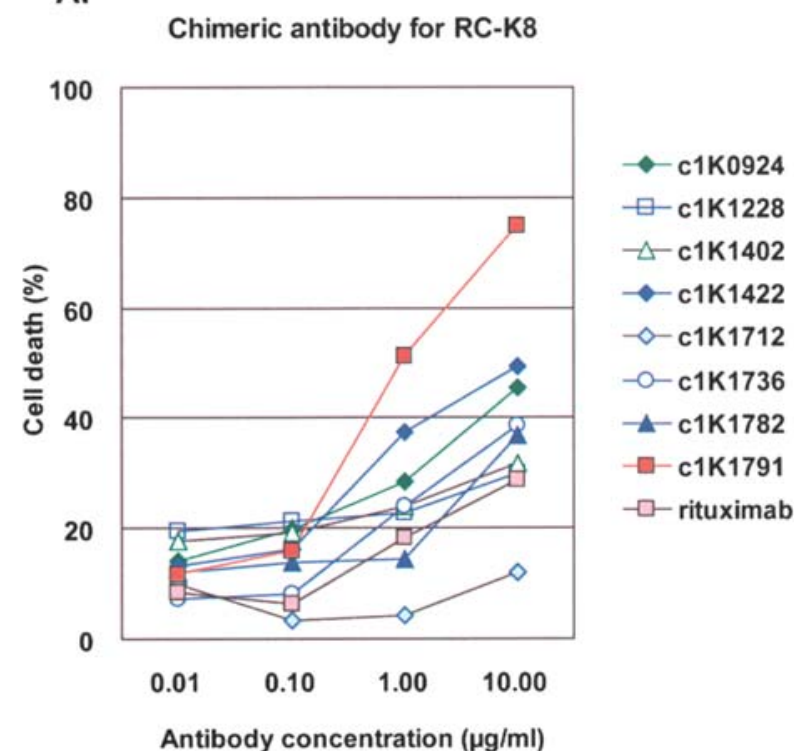

Antibody-dependent cellular cytotoxicity (ADCC). The chimeric and humanized anti-CD20 mAbs were tested for ADCC activity using human PBMCs derived from three normal donors as effectors and both radiolabeled RC-K8 and SU-DHL4 cells as targets. The ADCC activity of the chimeric mAbs against RC-K8 and SU-DHL4 cells varied from donor to donor although the level of cytotoxic activity was similar for all the antibodies tested. Rituximab was effective in inducing ADCC though slightly less than $\mathrm{c} 1 \mathrm{~K}$ mAbs (Fig. 2A and B). Similar findings were observed with the humanized mAbs though there were some differences among the antibodies tested, especially against RC-K8 (Fig. 2C and D). These findings from three different normal donors demonstrate that the chimeric and humanized mAbs exerted significant ADCC activities against two cell lines and that these were higher than those induced by rituximab or $2 \mathrm{~F} 2$.

Inhibitory effect for tumor cell proliferation. The humanized mAbs were tested for their inhibitory effect on RC-K8 and SU-DHL4 tumor cell growth. The tumor cells were incubated for $81 \mathrm{~h}$ (Raji) and $57 \mathrm{~h}$ (SU-DHL4) in the presence or absence of $0.5 \mu \mathrm{g} / \mathrm{ml}$ antibody. Cell growth was determined as described in Materials and methods. For RC-K8 humanized mAbs inhibited $20-40 \%$ of cell growth whereas rituximab or 2F2 showed only $15 \%$ inhibition (Fig. 3A). For SU-DHL4 the humanized mAbs inhibited a range of $30-50 \%$ whereas rituximab inhibited $50 \%$ and $2 \mathrm{~F} 2$ inhibited only $25 \%$ (Fig. 3B). Of note, the humanized sdr/abb, sdr/fra and sdr/sdr mAbs exhibited the more pronounced inhibitory effects against Raji and SU-DHL4 cells among the tested antibodies.

Induction of cytotoxic effects. The humanized mAbs were tested for cytotoxic activity against RC-K8 and Raji cells in
B.

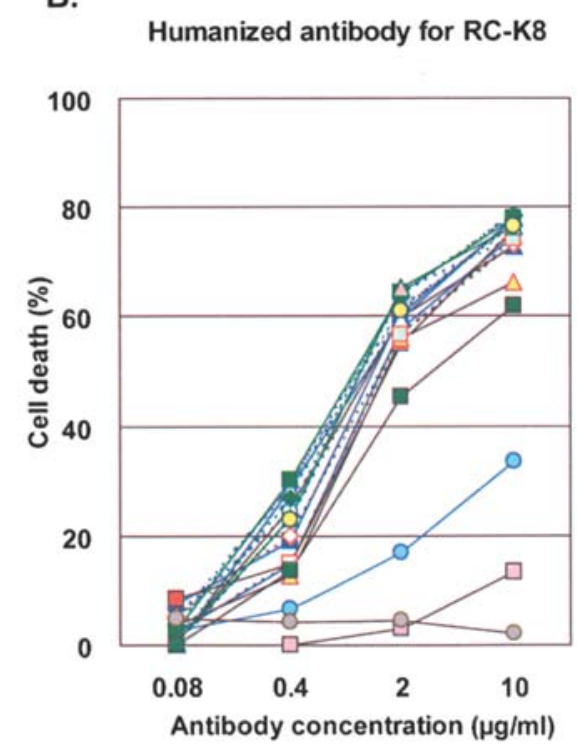

C.

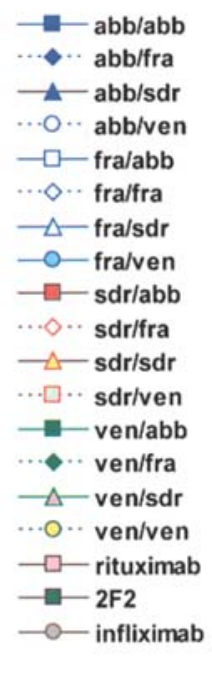

Humanized antibody for SU-DHL4

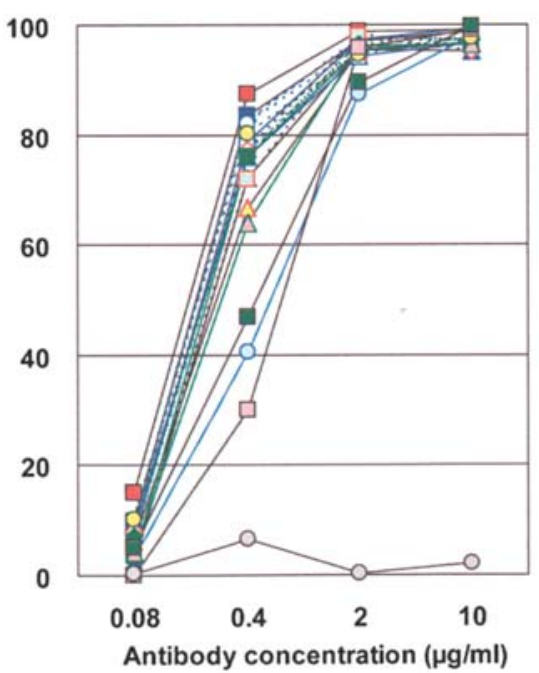

Figure 1. CDC induction by chimeric mAbs or humanized mAbs. CDC induction against RC-K8 cells by chimeric mAbs (A). CDC by humanized mAbs against RC-K8 or SU-DHL4 cells (B and C). Rituximab and infliximab were used as positive and negative controls respectively for the chimeric mAb study. Rituximab and $2 \mathrm{~F} 2$ were used as positive controls and infliximab as a negative control for humanized mAb studies. Tests were done in concentrationdependent manner for chimeric mAb study ranging from 0.01 to $10.00 \mu \mathrm{g} / \mathrm{ml}$ and for humanized mAb study ranging from 0.08 to $10.0 \mu \mathrm{g} / \mathrm{ml}$ based on the results of minimum concentration of antibody effectively induced CDC. The results of cell death (lysis) are shown graphically from 0 to $100 \%$ by adjusting $0 \%$ for (target cells + human serum complement) and 100\% for (target cells + Triton X-100). Samples were run in 3 replicates ( $\mathrm{n}=3$ ) for both chimeric and humanized mAbs. 
A.

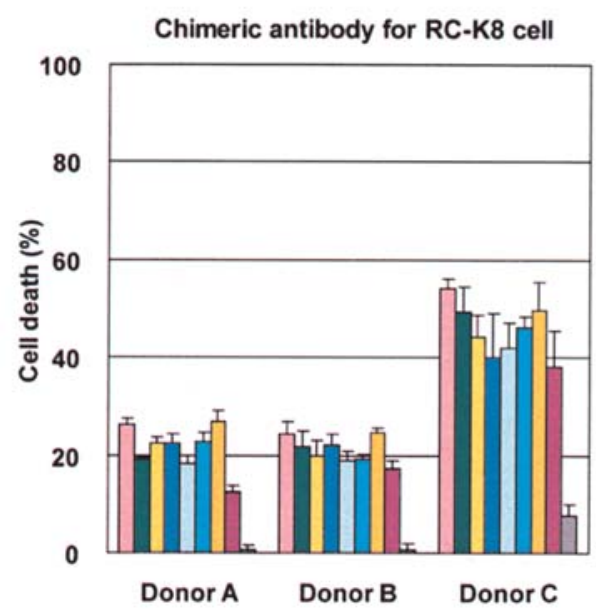

c.

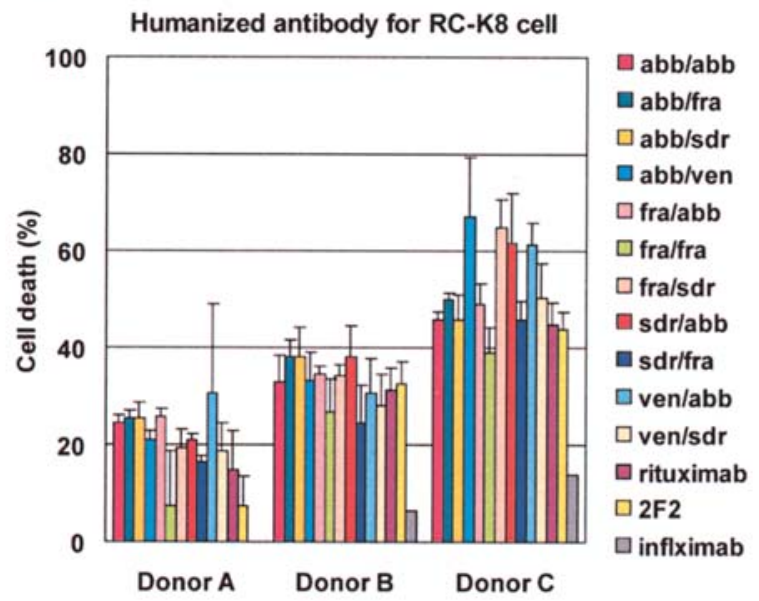

B.

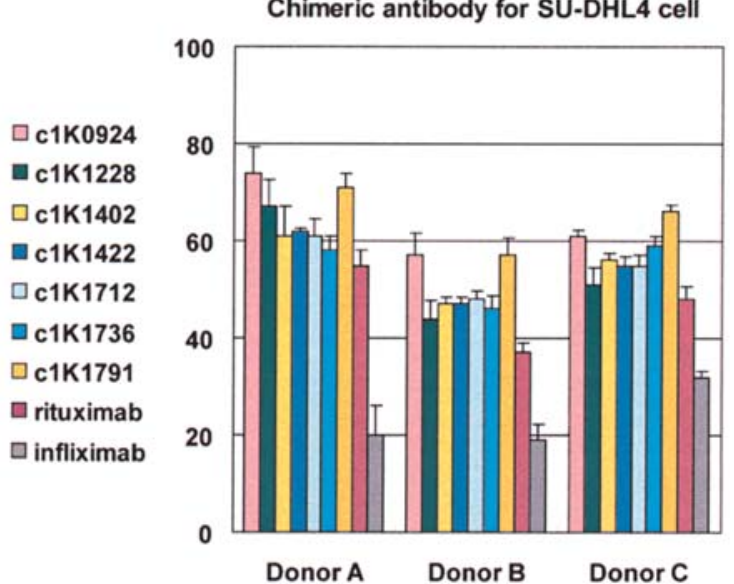

D.

Humanized antibody for SU-DHL4 cell

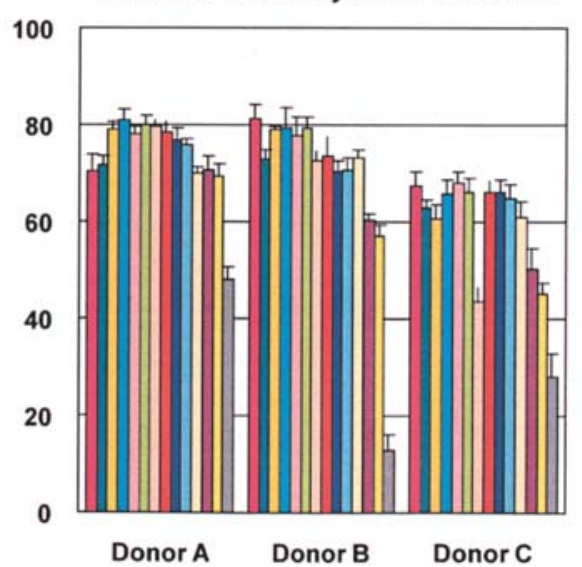

Figure 2. ADCC induction by chimeric or humanized mAbs. ADCC induction against RC-K8 or SU-DHL4 cells by chimeric mAbs (A and B), or by humanized mAbs (C and D) was measured using PBMCs from three donors (donors A, B and C). For studies on SU-DHL4 by humanized mAbs, donors B and C were substituted for other donors because of their unavailability at the requested time. Rituximab and infliximab were used as positive and negative controls respectively for the study of chimeric mAbs. Rituximab and $2 \mathrm{~F} 2$ were used as positive controls and infliximab as a negative control for humanized mAbs. The results of cell death (lysis) are shown graphically from 0 to $100 \%$ by adjusting $0 \%$ for (target cells + PBMCs) and $100 \%$ for (target cells + Triton X). Samples were run in 5 replicates $(n=5)$ for chimeric $m A$ bs and in 4 replicates $(n=4)$ for humanized mAbs.

the presence or absence of a secondary cross-linking antibody. Total cell death, apoptosis and necrosis were assessed as described in Materials and methods. Moderate cytotoxic effects were observed against RC-K8 cells with sdr/abb and sdr/fra and more significant cytotoxicity against Raji cells (Fig. 4A and C). By comparison, neither rituximab nor $2 \mathrm{~F} 2$ showed any effect. In the presence of cross-linking antibody, there were modest but significant increases in cytotoxicity with most of the mAbs, including rituximab and $2 \mathrm{~F} 2$ (Fig. 4B and D). These findings demonstrate that some humanized antibodies can induce a higher level of apoptosis in the presence or absence of a secondary cross-linking antibody relative to rituximab or $2 \mathrm{~F} 2$.

Apoptosis induction by humanized mAb is caspaseindependent. We previously reported (14) that the apoptosis induced by some murine anti-CD20 mAbs was caspaseindependent and consistent with the reports by other groups (28-30); including the observation that rituximab-mediated death in Raji cells lacked certain characteristic apoptotic features and appeared to be independent of the usual caspase cascade activity. Addition of rituximab $(10 \mu \mathrm{g} / \mathrm{ml})$ and crosslinking antibody $(10 \mu \mathrm{g} / \mathrm{ml})$ did not result in increased luminescence when compared to untreated cells, suggesting that rituximab does not activate caspase-3, 7 and 9 under these conditions (data not shown). Both substrates gave a titratable luminescence signal within the range of 1000-5000 cells. Independence of caspase- 3 and 7 activation was demonstrated using murine $1 \mathrm{~K}$ mAbs or humanized mAbs such as sdr/abb, sdr/fra and abb/abb wherein incubation of these antibodies with Raji cells did not result in an increase in luminescence (Fig. 5). Ionomycin, a positive control for induction of apoptosis, induced significant activation (80\%) of caspase-3/7 in Raji cells in the same assay, suggesting that anti-CD20 induced apoptosis or necrosis was caspaseindependent.

Affinity measurement and competitive binding assay by ${ }^{125} \mathrm{I}-$ labeled antibody. It is usually assumed that an antibody being bivalent binds to two independent non-interacting sites and 
A.

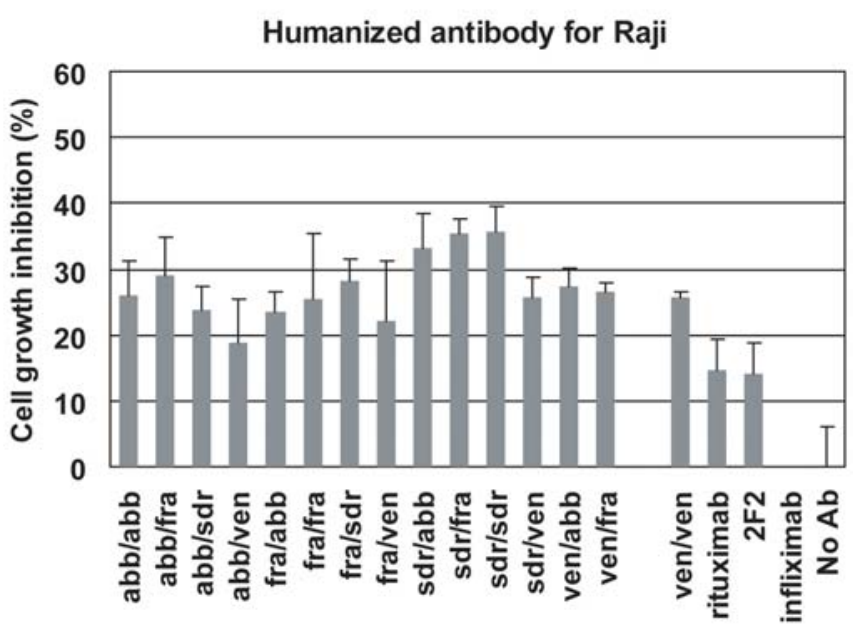

B.

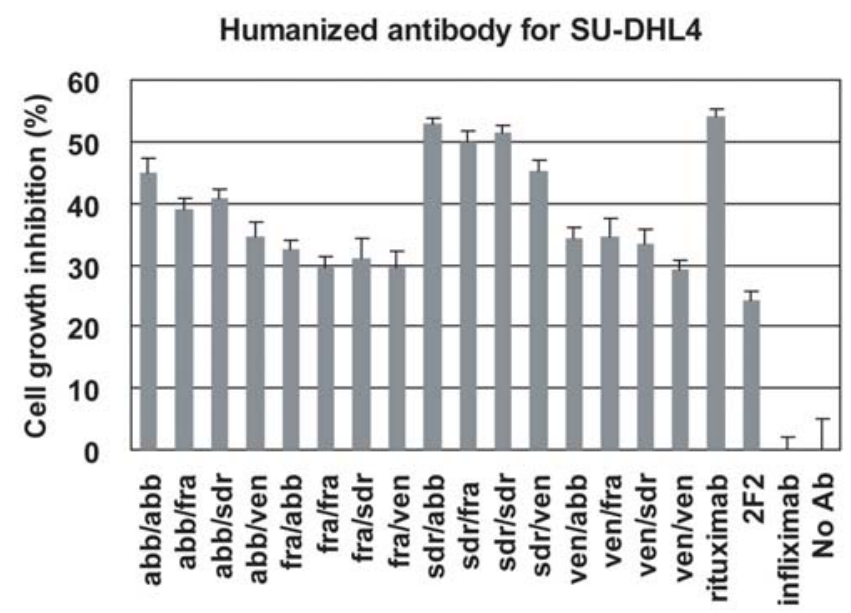

Figure 3. Direct inhibition of cell growth of Raji or SU-DHL4 cells by humanized mAbs. The growth of Raji and SU-DHL4 cells was measured in the presence of $0.5 \mu \mathrm{g} / \mathrm{ml}$ of each humanized $\mathrm{mAb}$ without effector components. The percentages of inhibitory effect in the figure are shown minus the percentage of the culture without antibody. The effect of each $\mathrm{mAb}$ against Raji cells was determined after $81 \mathrm{~h}$ culture and against SU-DHL4 cells after $57 \mathrm{~h}$ culture, respectively. Rituximab and $2 \mathrm{~F} 2$ were used as positive controls, and infliximab or the culture without antibody as negative controls. Ven/sdr was not available for the study of Raji cells. Samples were run in 4 replicates $(n=4)$ for humanized mAbs including control mAbs.

that binding to each site follows the law of mass action. In this study, we used GraphPad Prism software to individually analyze whether the binding of each antibody best fitted single-site or two-site binding kinetics through determination of $\mathrm{Kd}, \mathrm{B}_{\max }$ and $\mathrm{EC}_{50}$ (Table II). Most humanized antibodies had binding characteristics that fitted a two-site binding equation. The Kd values for the humanized mAbs ranged from 0.92 to $2.54 \mathrm{nM}$ while repeated measurements of $\mathrm{Kd}$ for rituximab gave an average value of $1.38 \mathrm{nM} . \mathrm{B}_{\max }$ values for the humanized mAbs were grouped into three, one ranged from $1.7-2.9 \times 10^{5} \mathrm{cpm}$ which was most common, a larger

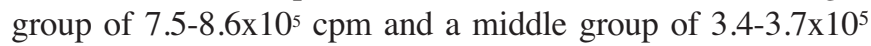
$\mathrm{cpm}$, although any correlation to physical or functional properties was not identified. The $\mathrm{EC}_{50}$ for each humanized anti-CD20 in competition with radiolabeled [ $\left.{ }^{125} \mathrm{I}\right]$-rituximab was measured using Raji cells in suspension. The humanized antibodies most competitive with rituximab were fra/abb, sdr/abb and fra/sdr and were equivalent or stronger than rituximab binding itself. Other humanized mAbs although weaker, still showed significant competition.

Relationship between biological properties of anti-CD20 $m A b s$ and their germline gene origin. There was no clear relationship between the variable region germline gene of origin for the various anti-CD20 mAbs (Table III) and their biological properties described in our previous study (14). Nevertheless, the murine antibody 1K1791 did exhibit significant inhibition of cell growth and apoptosis even without a secondary cross-linking antibody and the chimerized version of 1K1791 also demonstrated significant CDC and ADCC activity (Figs. 1 and 2). It is noteworthy because $1 \mathrm{~K} 1791$ was the only monoclonal antibody selected that was not derived from the VH1 gene family. The heavy-chain CDR3 region of 1K1791 was 15 amino acids long, which was the longest of any of the mAbs examined in this study. Rock et al examined 1620 murine $\mathrm{VH}$ regions and showed an average CDR3 length of 8-9 residues in the mouse (31).

Relationship between physical properties and biological properties of humanized $m A$ bs. The considerably larger $\mathrm{B}_{\max }$ of ven/abb, abb/sdr and abb/ven, almost four times larger than rituximab and other common humanized mAbs, did not show any correlation with any of their biological properties (Table II, Figs. 1-4). The Kd values also did not have any impact on the biological properties within $<3$-fold range. Sdr/abb and sdr/fra which demonstrated significant biological effects compared to rituximab, showed similar Kds (1.32, $1.33 \mathrm{nM}$, respectively whereas $1.38 \mathrm{nM}$ for rituximab) but $>2$-fold difference of $\mathrm{B}_{\max }\left(1.7 \times 10^{5}, 4.0 \times 10^{5}\right.$, respectively whereas $2.1 \times 10^{5}$ for rituximab). These results suggest the strongest binding is not a sufficient enough factor alone to induce the most potent cytotoxicity, inhibition of cell proliferation or apoptosis.

\section{Discussion}

The present study examined a number of anti-CD20 mAbs that were developed by us as well as some pre-existing antiCD20 mAbs whose properties and sequences have been published. We identified a chimeric antibody, c1K1791, which showed significantly enhanced functional activities compared to other antibodies including rituximab. The original murine antibody $1 \mathrm{~K} 1791$ was the top choice for humanization using four different methods to derive 16 humanized variants. Most of these humanized mAbs showed superior functional activity in comparison with rituximab and $2 \mathrm{~F} 2$.

In a recent study, we reported the unique activity of the murine 1K1791 anti-CD20 mAb over other generated mAbs, including 2B8 (the murine parent of rituximab). We pursued the development of chimeric and humanized antibodies from $1 \mathrm{~K} 1791$, therefore, with the objective of validating their unique features and their potential clinical applications. The present findings demonstrate that the chimeric mAb c1K1791 showed significant functional activities and humanization of $1 \mathrm{~K} 1791$ resulted in the generation of several mAbs that 
A.

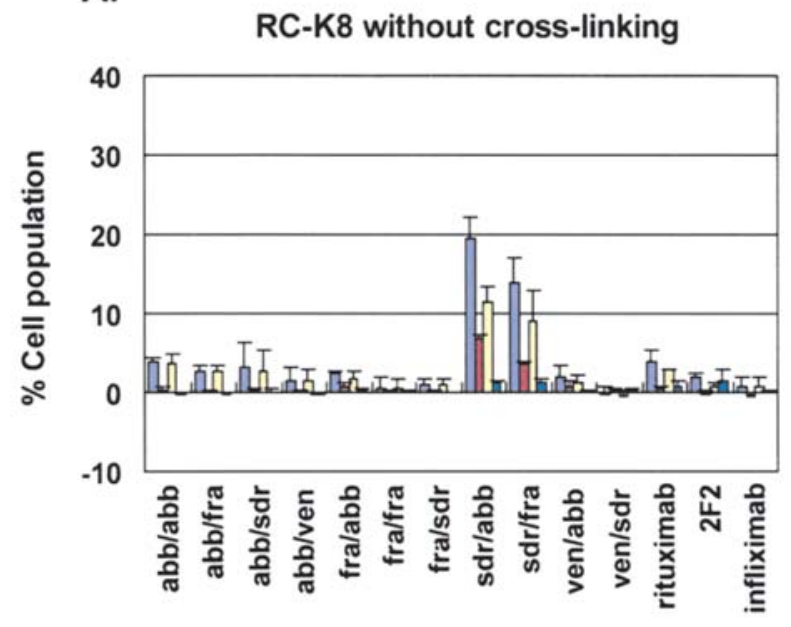

$\square$ Total Dead /Apoptotic $\square$ Apoptotic Dead

C.

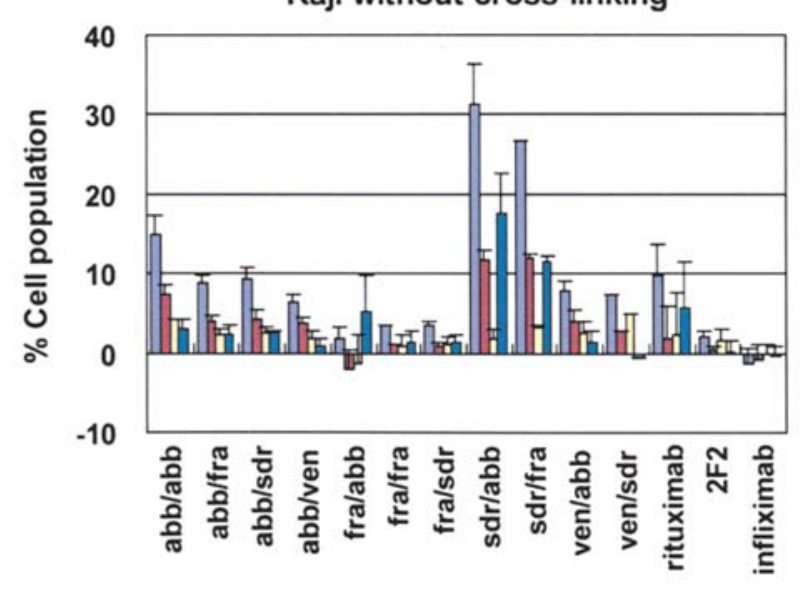

B.

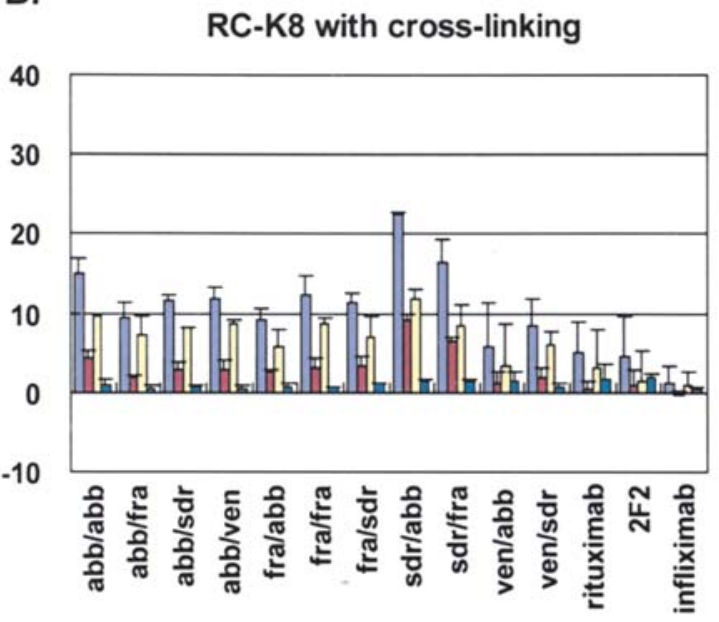

$\square$ Apoptotic Live $\square$ Necrotic Dead

D.

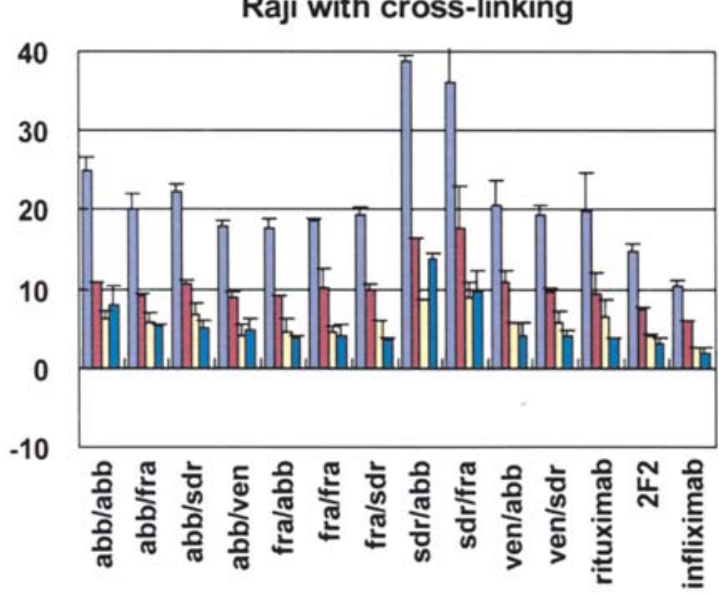

Figure 4. Analysis of cell death mediated by humanized mAbs. RC-K8 and Raji cells were treated with humanized mAbs for 24 h, without or with crosslinking antibody. This cell culture with antibody treatment was performed in duplicate. Apoptotic dead, apoptotic live and necrotic dead were measured by flow cytometry with Annexin V/FITC and PI staining. Rituximab and 2F2 were used for the comparison and infliximab as the negative control. Cells were incubated in duplicate with test or control antibodies $(10 \mu \mathrm{g} / \mathrm{ml})$, in the presence or absence of cross-linking antibody (10 $\mu \mathrm{g} / \mathrm{ml})$. The results of the flow cytometric analysis of RC-K8 cells either with or without cross-linking IgG (A and B) and that of Raji cells either with or without cross-linking IgG (C and D) were demonstrated.

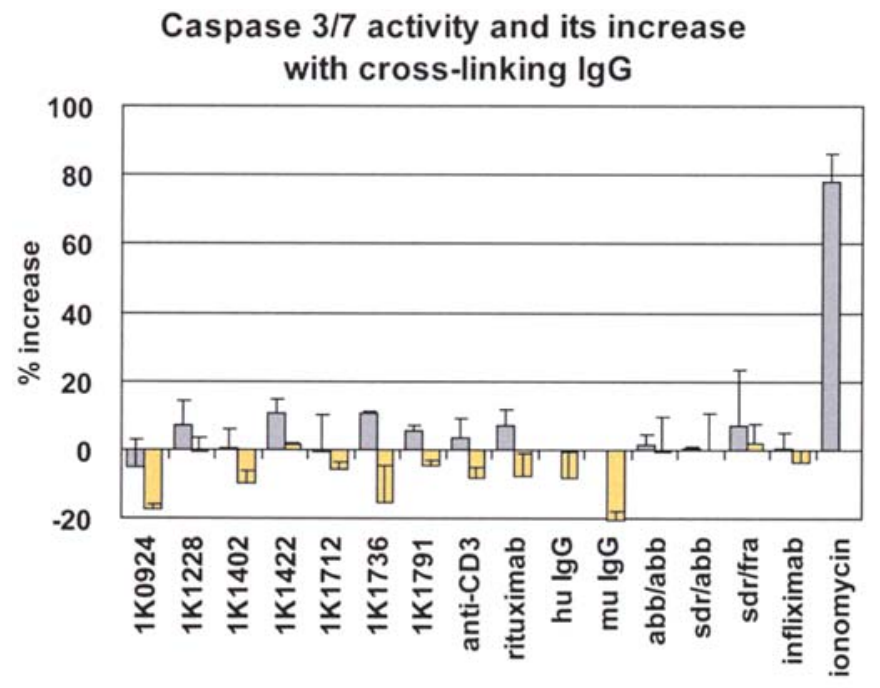

$\square$ Antibody without IgG $\square$ Antibody with IgG also retained such potent functional activities. These newly developed humanized antibodies were generally superior to rituximab and $2 \mathrm{~F} 2$ in many in vitro activities such as $\mathrm{CDC}$, ADCC, inhibition of cell growth and cell death including apoptosis. There were two humanized antibodies, sdr/abb and sdr/fra, that exerted more significant inhibition of cell growth and induction of cell death and these became candidates for potential follow-up of their anti-tumor effects in animals and in clinical trials.

Figure 5. Failure to activate caspase-3/7 by humanized or murine anti-CD20 $\mathrm{mAbs}$. Increase in caspase- $3 / 7$ activities with anti-CD20 mAbs, murine $1 \mathrm{~K}$ mAbs, humanized mAbs or rituximab were measured in Raji cells in the presence or absence of cross-linking antibody. Murine $\operatorname{IgG}(\mathrm{mu} \operatorname{IgG})$, human $\operatorname{IgG}$ (hu $\mathrm{IgG}$ ), anti-CD3 mAb and infliximab were used as negative controls. Ionomycin was used as a positive control for the induction of caspasedependent apoptosis also in Raji cells. All values are shown minus the value using cells with caspase-3/7 substrate alone. Ionomycin was tested without antibody. 
Table II. Binding affinities of humanized mAbs and competition against ${ }^{125}$ I-labeled rituximab.

\begin{tabular}{|c|c|c|c|c|c|c|c|}
\hline & \multicolumn{3}{|c|}{ Binding affinity } & \multicolumn{2}{|c|}{ Total amount bound } & \multicolumn{2}{|c|}{$\begin{array}{l}\text { Binding competition } \\
\text { with rituximab }\end{array}$} \\
\hline & $\mathrm{Kd}(\mathrm{nM})$ & SD & $\mathrm{R}^{2}$ & $\mathrm{~B}_{\max }$ & SD & $\mathrm{EC}_{50}(\mathrm{nM})$ & $\mathrm{R}^{2}$ \\
\hline $\mathrm{abb} / \mathrm{abb}$ & 1.624 & 0.006 & 0.992 & $2.8 \times 10^{5}$ & $2.0 \times 10^{4}$ & 51 & 0.971 \\
\hline $\mathrm{abb} / \mathrm{fra}$ & 1.936 & 0.011 & 0.993 & $2.3 \times 10^{5}$ & $2.4 \times 10^{4}$ & 71 & 0.983 \\
\hline $\mathrm{abb} / \mathrm{sdr}$ & 1.439 & 0.016 & 0.998 & $7.5 \times 10^{5}$ & $0.7 \times 10^{4}$ & 75 & 0.972 \\
\hline abb/ven & 1.360 & 0.005 & 0.993 & $7.7 \times 10^{5}$ & $3.4 \times 10^{4}$ & 51 & 0.874 \\
\hline $\mathrm{fra} / \mathrm{abb}$ & 0.927 & 0.001 & 0.996 & $2.1 \times 10^{5}$ & $0.7 \times 10^{4}$ & 14 & 0.918 \\
\hline fra/fra & 1.871 & 0.000 & 0.995 & $3.7 \times 10^{5}$ & $2.5 \times 10^{4}$ & 68 & 0.949 \\
\hline $\mathrm{fra} / \mathrm{sdr}$ & 1.016 & 0.001 & 0.996 & $2.4 \times 10^{5}$ & $0.84 \times 10^{4}$ & 37 & 0.919 \\
\hline $\mathrm{sdr} / \mathrm{abb}$ & 1.321 & 0.001 & 0.991 & $1.7 \times 10^{5}$ & $0.7 \times 10^{4}$ & 35 & 0.988 \\
\hline sdr/fra & 1.334 & 0.003 & 0.993 & $3.4 \times 10^{5}$ & $5.6 \times 10^{4}$ & 94 & 0.973 \\
\hline ven/abb & 2.537 & $\mathrm{n} / \mathrm{a}$ & 0.991 & $8.6 \times 10^{5}$ & $\mathrm{n} / \mathrm{a}$ & 54 & 0.934 \\
\hline ven/sdr & 1.456 & 0.007 & 0.999 & $2.9 \times 10^{5}$ & $1.9 \times 10^{4}$ & 66 & 0.804 \\
\hline rituximab & 1.382 & 0.013 & 0.996 & $2.1 \times 10^{5}$ & $0.9 \times 10^{4}$ & 38 & 0.982 \\
\hline
\end{tabular}

$\mathrm{Kd}$ and $\mathrm{B}_{\max }$ were determined in suspended Raji cells by non-linear regression analysis. The $\mathrm{EC}_{50}$ of each humanized mAb in competition with radiolabeled $\left[{ }^{125} \mathrm{I}\right]$-rituximab was analyzed using non-linear regression curve fitting using a single site parabolic curve fit. Raji cells were used as the target cell. $\mathrm{R}^{2}$, Correlation coefficient. $\mathrm{n} / \mathrm{a}$, not available.

Table III. Germline VL and VH gene recruitment.

\begin{tabular}{|c|c|c|c|c|c|c|}
\hline & \multirow[b]{2}{*}{ Isotype } & \multicolumn{2}{|c|}{ VL } & \multicolumn{3}{|c|}{$\mathrm{VH}$} \\
\hline & & Best germline fit & Family & Best germline fit & Family & CDR3 length \\
\hline B1 & $\operatorname{IgG} 1, \mathrm{k}$ & am4 & $\mathrm{Vk} 4 / 5$ & J558.9.99 & VH1 & 13 \\
\hline $2 \mathrm{H} 7$ & $\operatorname{IgG1,k}$ & $a m 4$ & $\mathrm{Vk} 4 / 5$ & J558.9.99 & VH1 & 13 \\
\hline $1 F 5$ & $\mathrm{IgG} 1, \mathrm{k}$ & am4 & $\mathrm{Vk} 4 / 5$ & $J 558.42$ & VH1 & 13 \\
\hline 2B8 & IgG1, k & am4 & $\mathrm{Vk} 4 / 5$ & $J 558.42$ & VH1 & 12 \\
\hline 1k0911 & $\operatorname{IgG} 2 \mathrm{~b}, \mathrm{k}$ & am4 & $\mathrm{Vk} 4 / 5$ & $J 558.42$ & VH1 & 10 \\
\hline 1K0924 & $\operatorname{IgG} 2 \mathrm{~b}, \mathrm{k}$ & am4 & $\mathrm{Vk} 4 / 5$ & $J 558.42$ & VH1 & 10 \\
\hline 1K1712 & $\operatorname{IgG} 2 \mathrm{a}, \mathrm{k}$ & am4 & $\mathrm{Vk} 4 / 5$ & $J 558.42$ & VH1 & 13 \\
\hline $1 \mathrm{k} 1728$ & IgG2a, k & am4 & $\mathrm{Vk} 4 / 5$ & $J 558.42$ & VH1 & 13 \\
\hline $1 \mathrm{k} 1409$ & $\mathrm{IgG1}, \mathrm{k}$ & am4 & $\mathrm{Vk} 4 / 5$ & $J 558.42$ & VH1 & 12 \\
\hline $1 \mathrm{k} 1773$ & $\mathrm{IgG} 2 \mathrm{~b}, \mathrm{k}$ & am4 & $\mathrm{Vk} 4 / 5$ & $J 558.42$ & VH1 & 13 \\
\hline $1 \mathrm{~K} 1402$ & $\operatorname{IgG1,~k~}$ & am4 & $\mathrm{Vk} 4 / 5$ & $J 558.42$ & VH1 & 12 \\
\hline $1 \mathrm{k} 1405$ & $\operatorname{IgG} 1, \mathrm{k}$ & am4 & $\mathrm{Vk} 4 / 5$ & $J 558.42$ & VH1 & 11 \\
\hline $1 \mathrm{k} 1428$ & $\operatorname{IgG} 1, \mathrm{k}$ & am4 & $\mathrm{Vk} 4 / 5$ & $J 558.42$ & VH1 & 12 \\
\hline $1 \mathrm{k} 1436 \mathrm{~A}$ & $\operatorname{IgG} 1, \mathrm{k}$ & $a m 4$ & $\mathrm{Vk} 4 / 5$ & $J 558.42$ & VH1 & 12 \\
\hline 1K1736 & $\operatorname{IgG} 2 \mathrm{~b}, \mathrm{k}$ & am4 (23-48) & $\mathrm{Vk} 4 / 5(\mathrm{Vk} 23)$ & $J 558.42$ & VH1 & 13 \\
\hline 1k1264 & $\mathrm{IgG1}, \mathrm{k}$ & al4 & $\mathrm{Vk} 4 / 5$ & $J 558.42$ & VH1 & 10 \\
\hline 1k1301B & IgG1, k & al4 & $\mathrm{Vk} 4 / 5$ & $J 558.42$ & VH1 & 12 \\
\hline 1k1316 & $\operatorname{IgG1}, \mathrm{k}$ & al4 & $\mathrm{Vk} 4 / 5$ & $J 558.42$ & VH1 & 12 \\
\hline 1K1228 & IgG1, k & $k f 4$ & $\mathrm{Vk} 4 / 5$ & $J 558.42$ & VH1 & 10 \\
\hline $1 \mathrm{k} 1257$ & IgG1, k & $k f 4$ & $\mathrm{Vk} 4 / 5$ & $J 558.42$ & VH1 & 10 \\
\hline 1K1422 & IgG1, k & af4 & $\mathrm{Vk} 4 / 5$ & J558.55.149 & VH1 & 14 \\
\hline 1K1782 & $\operatorname{IgG} 1, \mathrm{k}$ & $23-48$ & Vk23 & $J 558.45$ & VH1 & 7 \\
\hline 1K1791 & $\mathrm{IgG} 1, \mathrm{k}$ & $19-32$ & Vk19/28 & VH9.12 & VH9 & 15 \\
\hline
\end{tabular}

The best germline VL and VH fit was identified for each murine anti-CD20. The CDR3 length shown is for the heavy chain variable region. Vk of 1K1736 did not fit well to a specific germline Vk gene but had an am4- like 5' sequence and a 23-48-like 3' sequence. CDR3 length of $1 \mathrm{~K} 1791$ was the longest whereas that of $1 \mathrm{~K} 1782$ was the shortest. 
The augmented functional activities observed with 1K1791 and its chimeric and humanized derivatives prompted us to examine whether these activities are associated with $\mathrm{VH}$ and Vk germline gene sequences. In this study, 16/19 anti-CD20 antibodies that we developed were derived from the same VH germline gene, namely 'J558.42' and two closely related genes of the 'J558' group which belong to the VH1 family. The exception was the mAb $1 \mathrm{~K} 1791$ which used ' $V H 9.12$ ' belonging to the VH9 family. Examination of the light chain sequences showed that 17/19 anti-CD20 antibodies were from the $\mathrm{Vk} 4 / 5$ family and $21 / 23$ if the 4 published antiCD20 mAb sequences were included. $11 / 19 \mathrm{mAbs}$ used the ' am4' gene. 1K1791 was the only antibody to use the '19-32' gene which belonged to the Vk19/28 family. It is remarkable that so many antibodies independently generated against cell surface CD20 selected the same or closely related heavy and light variable region germline sequences.

Further examination of the published sequences for B1 and $2 \mathrm{H} 7$ showed minimal deviation from the germline $\mathrm{Vk}$ gene ' $a m 4$ ' and the heavy chain region showed $100 \%$ identity to the germline VH gene 'J588.9.99'. Little or no affinity maturation had occurred in these two antibodies. This germline gene combination, apparently, seems to have a natural affinity for the CD20 molecule without the need to undergo significant affinity maturation. 2B8 showed minor modifications from the germline $\mathrm{Vk}$ in the framework region and CDRs and only a single amino acid change in FR2 of the germline VH gene 'J558.42'. 1F5 also showed several changes in the $\mathrm{Vk}$ gene but only a single amino acid change in FR1 of the germline VH gene 'J558.42'.

It is possible that certain germline variable region genes have a 'pre-determined' affinity for certain antigens. There are precedents in the literature for this, for example, most murine antibodies against phosphatidylcholine have been shown to use the same VH11/Vk9 germline genes $(32,33)$. Autoantibodies in cold agglutinin disease stemming from lymphoproliferative disorders have been shown to be highly correlated with the use of the human VH4-34 gene (34). The lack of extensive mutation due to affinity maturation and the predominant use of the same germline gene seen in the antibodies we describe may well be due to the paucity of strong immunogenic $\mathrm{T}$ cell epitopes on CD20 and/or reflect the highly conserved nature of the molecule. Alternatively, the gene families used by 1K1791 may recognize certain epitopes that either impart an enhanced ability to cross-link the CD20 molecule or promote its localization to lipid rafts. Cragg et al (35) have shown this to be a prerequisite for intracellular signaling by bringing together other cell surface molecules such as BCR, src, CD52. However, Chan et al (28) have stated that cross-linking of CD20 alone is insufficient to promote localization to lipid rafts and quote B1 as an example of an antibody unable to promote localization of CD20 into this compartment, even though B1 is a potent inducer of apoptosis.

Another intriguing observation is that many of the immunoglobulin molecules isolated from CLL cells share common germline sequences. Johnson et al (36) observed that $63 \%$ of CLL patients with functional VH gene rearrangements expressed VH1-69. The D and J region usage was restricted and, in addition, the average length of the heavy chain CDR3 was longer than that for normal B cells. These exhibit very similar characteristics to those seen by us in the murine antibodies raised against CD20. CLL cells are believed to arise from a minority population of B cells, the so called $\mathrm{CD}^{+}$subset, the equivalent cells in the mouse being the Ly-1B subset. It may be possible that monoclonal antibodies against human CD20 arise from a relatively restricted set of cells, such as the Ly1-b subset. Alternatively, CD20 may be highly specific in selecting B cells with a predetermined $\mathrm{VH}$ gene and $\mathrm{Vk}$ gene usage, and longer than average CDR3 regions, that have a high natural affinity for it without the need for extensive affinity maturation.

Teeling et al (10) reported that some of the anti-CD20 antibodies they tested recognized a region in the small loop of CD20 whereas other CD20 mAbs bound to the large loop of CD20 $(3,37)$. There could also be such differential recognition of the small or large loops of CD20 among our $1 \mathrm{~K}$ mAbs. However, examination of many of the biological properties of the $1 \mathrm{~K} \mathrm{mAbs}, \mathrm{c} 1 \mathrm{~K} \mathrm{mAbs}$ and humanized mAbs derived from $1 \mathrm{~K} 1791$, as well as $2 \mathrm{~F} 2$ and rituximab, showed that emphasis on the recognition of either small or large loops may not be predictive. Elucidating the mechanism of apoptosis induction may likely prove more important than the localization of the epitopes. Cardarelli et al (38), later confirmed by Cragg and Glennie (37), demonstrated that $\mathrm{B} 1$ and its $\mathrm{F}\left(\mathrm{ab} \mathrm{b}^{\prime}\right)_{2}$ could induce apoptosis of B cells directly, even in the absence of secondary cross-linking by anti-IgG. The apoptosis induced by $1 \mathrm{~K} 1791$ and its humanized mAbs was found to be caspase-independent consistent with the findings of Chan et al (28) for other anti-CD20 mAbs.

All humanized mAbs except fra/ven induced significant and similar CDC in both RC-K8 and SU-DHL4 cells which was far stronger than rituximab or $2 \mathrm{~F} 2$. It was notable that $\mathrm{RC}-\mathrm{K} 8$ cells were extremely resistant to rituximab. Similarly, ADCC against SU-DHL4 was similar among the humanized mAbs with different donors of PBMCs and all of these mAbs demonstrated stronger ADCC activity than rituximab or $2 \mathrm{~F} 2$. However, the level of ADCC activity achieved using RC-K8 as target cells varied among different donors and also among humanized mAbs.

The relationship between antibody structure, binding affinity and epitope recognition is a very complex one. In the present study, the best antibody that we have developed originated from a different gene family compared to all others tested or from those previously published in the scientific literature. However, with only one example of the heavy chain VH9 or the light chain Vk19/28 family it is premature to draw conclusions on the significance of these gene families and their associated functions. Furthermore, different methods of humanization affected and even enhanced the activity of IK1791. This finding is supported by evidence from the comparison of sequences of framework region and CDRs (Table III), and their functional activities represented in Figs. 1-4. Even a very small number of amino acid replacements (made predominantly in the framework regions) gave a diversified response in apoptosis induction although the affinity, $\mathrm{CDC}$ and $\mathrm{ADCC}$ remained relatively unchanged. One could speculate that future selection of mAbs based on gene family rather than antigen affinity may yield antibodies with different functional activities. 
Our present study resulted in the selection of a specific humanized version sdr/abb of $1 \mathrm{~K} 1791$ that exhibited enhanced functional activities, compared to other antibodies that were developed, but also compared to other published and approved anti-CD20 mAbs. Future studies will be aimed at validating selected humanized antibodies in preclinical animal models that showed strongest in vitro activities. In addition, we will select those mAbs that can be developed for clinical trials to examine whether a humanized anti-CD20 antibody with different or enhanced functional activities will respond to refractory or recurrent B-cell malignancies. Such novel mAbs will also improve the response rates among a broader population of B-NHL patients.

\section{Acknowledgments}

The authors acknowledge Dr Benjamin Bonavida (UCLA) for assisting in the revision and advising in the preparation of this manuscript. Also, we acknowledge the researchers at the Bacteriology Division, Faculty of Medicine, Tottori University for their technical assistance.

\section{References}

1. Golay J, Zaffaroni L, Vaccari T, Lazzari M, Borleri GM, Bernasconi S, Tedesco F, Rambaldi A and Introna M: Biologic response of B lymphoma cells to anti-CD20 monoclonal antibody rituximab in vitro: CD55 and CD59 regulate complementmediated cell lysis. Blood 95: 3900-3908, 2000.

2. Semac I, Palomba C, Kulangara K, Klages N, van EchtenDeckert G, Borisch B and Hoessli DC: Anti-CD20 therapeutic antibody rituximab modifies the functional organization of rafts/ microdomains of B lymphoma cells. Cancer Res 15: 534-540, 2003.

3. Deans JP, Haidong LI and Polyak MJ: CD20-mediated apoptosis signaling through lipid rafts. Immunology 107: 176-182, 2002.

4. Jazirehi AR and Bonavida B: Cellular and molecular signal transduction pathways modulated by rituximab (rituxan, antiCD20 mAb) in non-Hodgkin's lymphoma: implications in chemosensitization and therapeutic intervention. Oncogene 24: 2121-2143, 2005.

5. Jazirehi AR, Huerta-Yepez S, Cheng G and Bonavida B: Rituximab (chimeric anti-CD20 monoclonal antibody) inhibits the constitutive nuclear factor-\{kappa\}B signaling pathway in non-Hodgkin's lymphoma B-cell lines: role in sensitization to chemotherapeutic drug-induced apoptosis. Cancer Res 65: 264-276, 2005

6. Deans JP, Schieven GL, Shu GL, Valentine MA, Gilliland LA, Aruffo A, Clark EA and Ledbetter JA: Association of tyrosine and serine kinases with the B cell surface antigen CD20. Induction via CD20 of tyrosine phosphorylation and activation of phospholipase C-gamma 1 and PLC phospholipase C-gamma 2. J Immunol 151: 4494-4504, 1993.

7. Polyak MJ and Deans JP: Alanine-170 and proline-172 are critical determinants for extracellular CD20 epitopes; heterogeneity in the fine specificity of CD20 monoclonal antibodies is defined by additional requirements imposed by both amino acid sequence and quaternary structure. Blood 99: 3256-3262, 2002.

8. Polyak MJ, Tailor SH and Deans JP: Identification of a cytoplasmic region of $\mathrm{CD} 20$ required for its redistribution to a detergent-insoluble membrane compartment. J Immunol 161: 3242-3248, 1998

9. Perosa F, Favoino E, Caragnano MA and Dammacco F: Generation of biologically active linear and cyclic peptides has revealed a unique fine specificity of rituximab and its possible cross-reactivity with acid sphingomyelinase-like phospho-diesterase 3b precursor. Blood 107: 1070-1077, 2006.

10. Teeling JL, Mackus WJ, Wiegman LJ, van den Brakel JH, Beers SA, French RR, van Meerten T, Ebeling S, Vink T, Slootstra JW, Parren PW, Glennie MJ and van de Winkel JG: The biological activity of human CD20 monoclonal antibodies is linked to unique epitopes on CD20. J Immunol 177: 362-371, 2006.
11. Glennie MJ, French RR, Cragg MS and Taylor RP: Mechanism of killing by anti-CD20 monoclonal antibodies. Mol Immunol 44: 3823-3837, 2007.

12. Golay J, Gramigna R, Facchinetti V, Capello D and Introna M: Acquired immunodeficiency syndrome-associated lymphomas are efficiently lysed through complement-dependent cytotoxicity and antibody-dependent cellular cytotoxicity by rituximab. Br J Haematol 119: 923-929, 2002.

13. Teeling JL, French RR, Cragg MS, van den Brakel J, Pluyter M, Huang H, Chan C, Parren PW, Hack CE, Dechant M, Valerius T, van de Winkel JG and Glennie MJ: Characterization of new human CD20 monoclonal antibodies with potent cytolytic activity against non-Hodgkin lymphomas. Blood 104: 1793-1800, 2004.

14. Nishida M, Usuda S, Okabe M, Miyakoda H, Komatsu M, Hanaoka $\mathrm{H}$, Teshigawara $\mathrm{K}$ and Niwa $\mathrm{O}$ : Characterization of novel murine anti-CD20 monoclonal antibodies and their comparison to 2B8 and c2B8 (rituximab). Int J Oncol 31: 29-40, 2007.

15. Urlaub G, Mitchell PJ, Kas E, Chasin LA, Funanage VL, Myoda TT and Hamlin J: Effect of gamma rays at the dihydrofolate reductase locus: deletions and inversions. Somat Cell Mol Genet 12: 555-566, 1986.

16. Teeling J, Ruuls S, Glennie M, von de Winkel JDG, Parren P, Petersen J, Baadsgaard $\mathrm{O}$ and Huang $\mathrm{H}$ : Human monoclonal antibody against CD20. United State Patent Publication No. US 2004/0167319 A1, 2004.

17. Johnston CM, Wood AL, Bolland DJ and Corcoran AE: Complete sequence assembly and characterization of the C57BL/6 mouse Ig heavy chain V region. J Immunol 176: 4221-4234, 2006.

18. Thiebe R, Schäble KF, Bensch A, Brensing-Küppers J, Heim V, Kirschbaum T, Mitlöhner H, Ohnrich M, Pourrajabi S, Röschenahaler F, Schwendinger J, Wichelhaus D, Zocher I and Zachau HG: The variable genes and gene families of the mouse immunoglobulin kappa locus. Eur Immunol 29: 2072-2081, 1999

19. Brekke KM and Garrard WT: Assembly and analysis of the mouse immunoglobulin kappa gene sequence. Immunogenetics 56: 490-505, 2004.

20. Ohtani K, Suzuki Y, Eda S, Kawai T, Kase T, Keshi H, Sakai Y, Yamamoto S, Sakamoto T and Wakamiya N: Highlevel and effective production of human mannan-binding lectin (MBL) in Chinese hamster ovary (CHO) cells. J Immunol Methods 222: 135-144, 1999.

21. Padlan EA: A possible procedure for reducing the immunogenicity of antibody variable domains while preserving their ligand-binding properties. Mol Immunol 28: 489-498, 1991.

22. Padlan EA, Abergel C and Tipper JP: Identification of specificity-determining residues in antibodies. FASEB J 9: 133-139, 1995 .

23. Wu TT and Kabat EA: Possible use of similar framework region amino acid sequences between human and mouse immunoglobulin for humanizing mouse antibodies. Mol Immunol 29: 1141-1146, 1992.

24. Gazzano-Santoro H, Ralph P, Ryskamp TC, Chen AB and Mukku VR: A non-radioactive complement-dependent cytotoxicity assay for anti-CD20 monoclonal antibody. J Immunol Methods 202: 163-171, 1997.

25. Idusogie EE, Presta LG, Gazzano-Santoro H, Totpal K, Wong PY, Ultsch M, Meng G and Mulkerrin MG: Mapping of the C1q binding site on Rituxan, a chimeric antibody with a human IgG1 Fc. J Immunol 164: 4178-4184, 2000.

26. Rose AL, Smith BE and Maloney DG: Glucocorticoids and rituximab in vitro: synergistic direct antiproliferative and apoptotic effects. Blood 100: 1765-1773, 2002

27. GraphPad Software, Inc: Fitting Models to Biological Data Using Linear and Nonlinear Regression, 2003.

28. Chan HT, Hughes D, French RR, Tutt AL, Walshe CA, Teeling JL, Glennie MJ and Cragg MS: CD20-induced lymphoma cell death is independent of both caspases and its redistribution into triton X-100 insoluble membrane rafts. Cancer Res 63: 5480-5489, 2003.

29. Stanglmaier M, Reis S and Hallek M: Rituximab and alemtuzumab induce a non-classic caspase-independent apoptotic pathway in B-lymphoid cell lines and in chronic lymphocytic leukemia cells. Ann Hematol 83: 634-645, 2004.

30. Daniels I, Abulayha AM, Thomson BJ and Haynes AP: Caspase-independent killing of Burkitt lymphoma cell lines by rituximab. Apoptosis 11: 1013-1023, 2006. 
31. Rock EP, Sibbald PR, Davis MM and Chien YH: CDR3 length in antigen-specific immune receptors. J Exp Med 179: 323-328, 1994.

32. Seidl KJ, MacKenzie JD, Wang D, Kantor AB, Kabat EA, Herzenberg LA and Herzenberg LA: Frequent occurrence of identical heavy and light chain Ig rearrangement. Int Immunol 9: 689-702, 1997.

33. Arnold LW, Spencer DH, Clarke SH and Haughton G: Mechanisms that limit the diversity of antibody: three sequentially acting mechanisms that favor the spontaneous production of germline encoded anti-phophatidyl choline. Int Immunol 5: 1365-1373, 1993

34. Li Y, Spellerberg MB, Stevenson FK, Capra JD and Potter KN: The I binding specificity of human VH 4-34 (VH 4-21) encoded antibodies is determined by both $\mathrm{VH}$ framework region 1 and complementarity determining region 3. J Mol Biol 256: 577-589, 1996.
35. Cragg MS, Morgan SM, Chan HT, Morgan BP, Filatov AV, Johnson PW, French RR and Glennie MJ: Complement mediated lysis by anti-CD20 mAb correlates with segregation into lipid rafts. Blood 101: 1045-1052, 2003.

36. Johnson TA, Rassenti LZ and Kipps TJ: Ig VH1 genes expressed in B cell chronic lymphocytic leukemia exhibit distinctive molecular features. J Immunol 158: 235-246, 1997.

37. Cragg MS and Glennie MJ: Antibody specificity controls in vivo effector mechanisms of anti-CD20 reagents. Blood 103: 2738-2743, 2004.

38. Cardarelli PM, Quinn M, Buckman D, Fang Y, Colcher D, King DJ, Bebbington $\mathrm{C}$ and Yarranton G: Binding to CD20 by anti-B 1 antibody or $F\left(a b^{\prime}\right) 2$ is sufficient for induction of apoptosis in B-cell lines. Cancer Immunol Immunother 51: 15-24, 2002. 